[Type text]

\title{
NUTRITIONAL ASSESSMENT AND ASSOCIATED FACTORS IN CHILDREN WITH CONGENITAL HEART DISEASE - ETHIOPIA
}

AUTHOR

Dr. Tigist Tesfaye (MD, Pediatrician)

Saint Peter medical college, Addis Ababa, Ethiopia.

Email: tigist.tesfaye@sphmmc.edu.et

Alt. Email: Tgbigotg@gmail.com

Phone No. +251912349006

\section{CO-AUTHORS}

1. Dr. Temesgen Tsega (Pediatrician, Cardiologist)

Department of pediatrics and child health

Saint Paul hospital millennium Medical college

Email: yafettemu@gmail.com

Phone No. +251911023103

2. Dr. Azene Dessie (Pediatrician, Cardiologist )

Children Cardiac center - Ethiopia

Email: admengistu2000@yahoo.com

Phone No. +251918763686

3. Mr. Tesfalem Teshome (MPH)

Saint Paul hospital millennium Medical college

Department of public health

Email: tesfabemnet2005@gmail.com

CORRESPONDING AUTHOR: Dr. Temesgen Tsega 
medRxiv preprint doi: https://doi.org/10.1101/2021.04.12.21255315; this version posted April 19, 2021. The copyright holder for this preprint (which was not certified by peer review) is the author/funder, who has granted medRxiv a license to display the preprint in perpetuity.

All rights reserved. No reuse allowed without permission.

[Type text]

TABLE OF CONTENT 
medRxiv preprint doi: https://doi.org/10.1101/2021.04.12.21255315; this version posted April 19, 2021. The copyright holder for this preprint (which was not certified by peer review) is the author/funder, who has granted medRxiv a license to display the preprint in perpetuity. All rights reserved. No reuse allowed without permission.

[Type text]

TABLE OF CONTENT 3

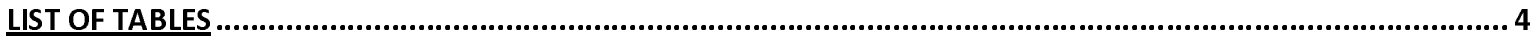

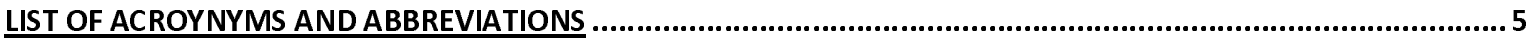

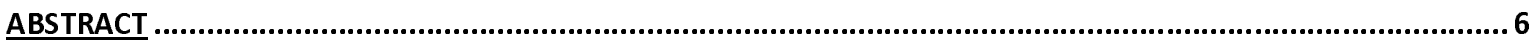

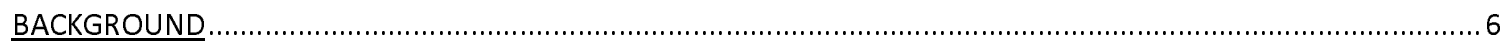

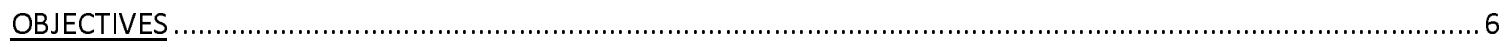

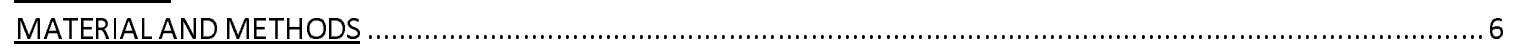

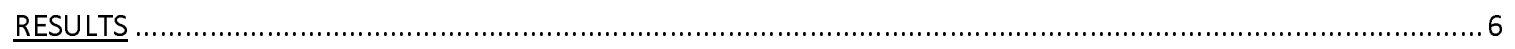

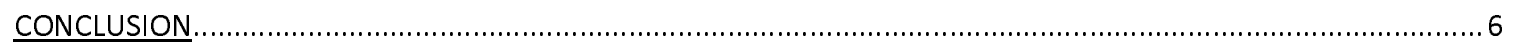

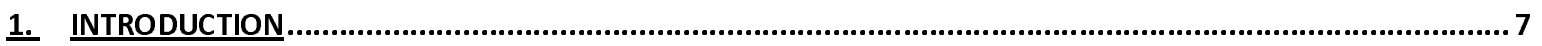

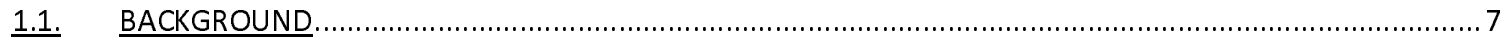

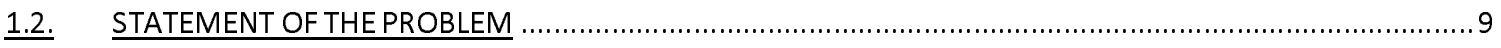

1.3. SIGNIFICANCE OF THE STUDY .............................................................. ERRoR! BooKMARK Not DEFINED.

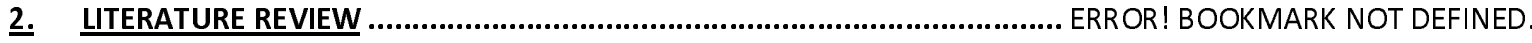

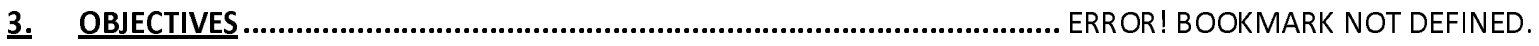

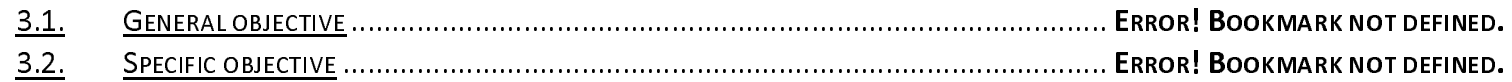

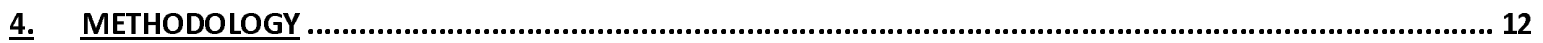

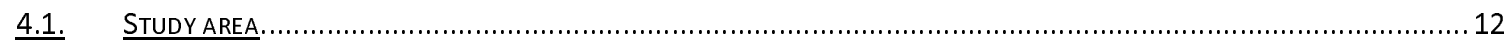

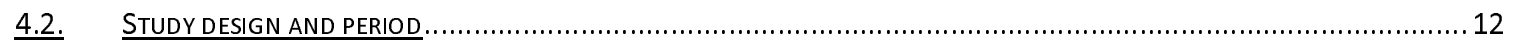

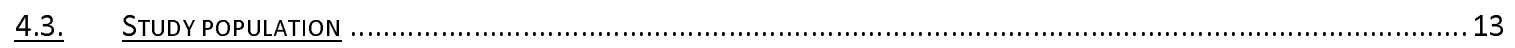

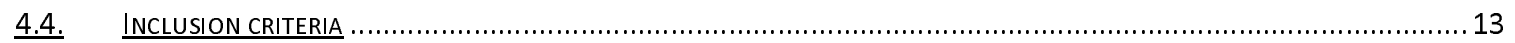

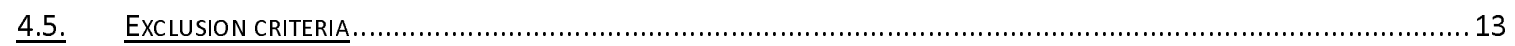

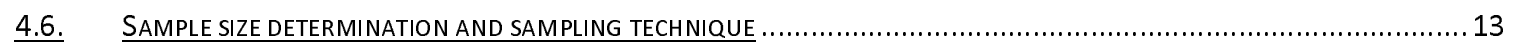

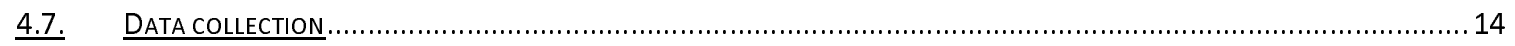

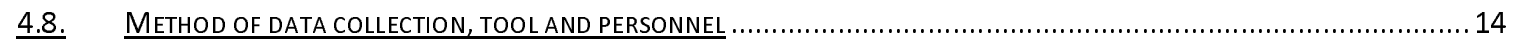

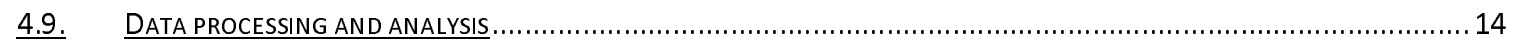

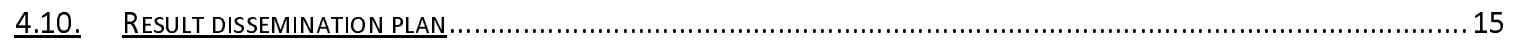

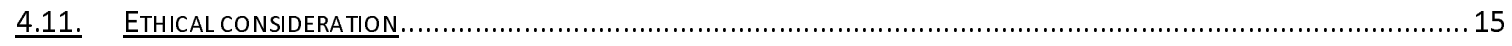

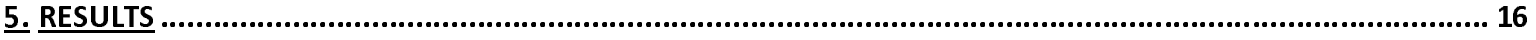

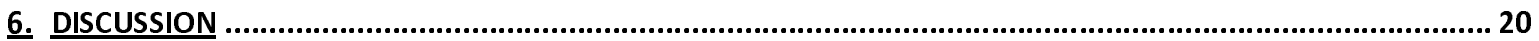

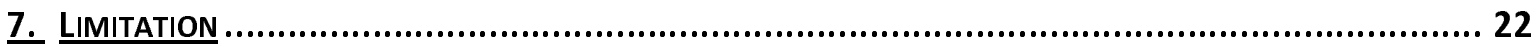

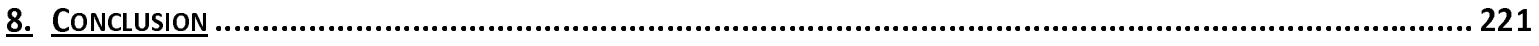

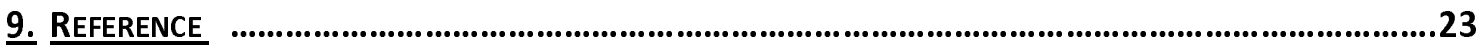

10. Declaration of conflict of interest.................................................24 
medRxiv preprint doi: https://doi.org/10.1101/2021.04.12.21255315; this version posted April 19, 2021. The copyright holder for this preprint (which was not certified by peer review) is the author/funder, who has granted medRxiv a license to display the preprint in perpetuity. All rights reserved. No reuse allowed without permission.

[Type text]

\section{LIST OF TABLES}

Table 1: socio-demographic data.

Table 2: Clinical profile of CHD patients.

Table 3: The types of cardiac defects and their prevalence among the study groups

Table 4: Comparison of CHD patients with and without pulmonary hypertension based on their nutritional status.

Table 5: Bivariate and multivariate analysis

Table 5a: Bivariate and multivariate analysis for Underweight

Table 5b: Bivariate and multivariate analysis for wasting

Table 5c: Bivariate and multivariate analysis for stunting 
medRxiv preprint doi: https://doi.org/10.1101/2021.04.12.21255315; this version posted April 19, 2021. The copyright holder for this preprint (which was not certified by peer review) is the author/funder, who has granted medRxiv a license to display the preprint in perpetuity. All rights reserved. No reuse allowed without permission.

[Type text]

\section{LIST OF ACROYNYMS AND ABBREVIATIONS}

ASD : atrial septal defect

AS : aortic stenosis

AVSD : atrioventricular septal defect

CCC : children's cardiac center

CHD : congenital heart disease

CHF : congestive heart disease

CoA : coarctation od aorta

OPD : outpatient department

PA : pulmonary atresia

PAH : pulmonary arterial hypertension

PDA : patent ductus arteriosus

PI : primary investigator

PS : pulmonary stenosis

SPMMC : St. Paul hospital millennium medical college

SPSS : Statistical package for social science

TA : truncus arteriosus

TAPVR : total anomalous pulmonary venous return

TGA : trans-position of great arteries

TOF : tetralogy of Fallot

VSD : ventricular septal defect

WHO : world health organization 
medRxiv preprint doi: https://doi.org/10.1101/2021.04.12.21255315; this version posted April 19, 2021. The copyright holder for this preprint (which was not certified by peer review) is the author/funder, who has granted medRxiv a license to display the preprint in perpetuity.

All rights reserved. No reuse allowed without permission.

[Type text]

\section{ABSTRACT}

Worldwide, congenital heart disease is the principal heart diseases in children and constitutes one of the major causes of infant mortality, particularly in developing countries. Infants and children with congenital heart disease exhibit a range of delays in weight gain and growth. In some instances, the delay can be relatively mild, whereas in other cases, cause the failure to thrive.

\section{OBJECTIVES}

To determine the nutritional status and associated factors of pediatric patients with congenital heart disease.

\section{MATERIAL AND METHODS}

A cross sectional analytical study was done over a period of 6months (Feb to Jul 2020). A total of 228 subjects with congenital heart disease that come to the cardiac center during the study period where included until the calculated sample size was attained. Data was collected from patient card and care givers of the children included in the study after obtaining their informed consent using data inquiry sheet. Data was then analyzed using Statistical Package for Social Sciences (SPSS) for windows version 25.0. Data is presented using tables and text form. Odds Ratio with 95\% Confidence Interval (CI) was used to determine the effect of the independent variables on the outcome variable and Pvalue less than 0.05 was considered statistically significant.

\section{RESULTS}

A total of 228 children from age 3 month to $17 y$ rs with mean age of 4.7 years $(S D=3.8$ years) were included in the study. Most of the subjects had acyanotic heart disease accounting for $87.7 \%$. The overall prevalence of wasting, underweight and stunting were $41.3 \%, 49.1 \%$ and $43 \%$ respectively. Among this children with congenital heart disease those with $\mathrm{PAH}$ were found more likely have wasting compared to those without PAH with an odds of 1.9 (95\% CI: 1.0-3.4) and also greater chance of being stunted with an odds of 1.9 (95\% CI: 1.0-3.4). children above 5years of age were 2.3 times more likely to be underweight.

\section{CONCLUSION}

Malnutrition is a major problem of patients with CHD. Pulmonary hypertension and older age are associated with increased risk of undernutrition.

KEY WORDS: Acyanotic congenital heart disease, cyanotic congenital heart disease, Pulmonary hypertension, underweight, wasting and stunting. 
[Type text]

\section{INTRODUCTION}

\subsection{BACKGROUND}

Congenital heart disease (CHD) is a defect in the heart or major blood vessels that are present in children at birth \& occurs in approximately $1 \%$ of live births. It is usually defined as clinically significant structural heart disease present at birth.(2)

Worldwide, CHD is the principal heart diseases in children and constitutes one of the major causes of infant mortality, particularly in developing countries(3). Infants and children with CHD exhibit a range of delays in weight gain and growth. In some instances, the delay can be relatively mild, whereas in other cases, it could be severe causing failure to thrive (4).

Good nutrition is essential for survival, physical growth, mental development, performance, productivity, health and well-being across the entire life span from the earliest stages of fetal development, at birth, and through infancy, childhood, adolescence and on into adulthood (4). Infants and children are more likely to suffer from poor nutrition than compared to adults. The first reason is newborn infants have low stores of fat and protein. The smaller the child, the fewer reserves of energy they have. This means that they can only cope with starvation for shortened periods. The second reason is high nutritional demands for growth: The amount of nutrition children require is greatest during infancy, because of their rapid growth during this period. The third reason is rapid development in the nervous system: the child's brain grows rapidly during the last four months of pregnancy and also during the first two years of the life. The connections between the nerve cells in the brain are being formed during this time therefore good nutrition is important to ensure that this occurs properly. The fourth reason is Illness: the child's nutrition may be compromised following an episode of illness or surgery. The body's energy requirements are increased; thus intake of food and nutrients should be increased (4-6). 
[Type text]

Prevalence of growth failure is estimated to be $64 \%$ in children with CHD living in developed countries while this number likely to be higher in those living in developing countries for the reason than malnutrition perse is much more common because of other additional factors.

Multiple factors are mentioned in literatures to answer why would patients with CHD develop malnutrition. These are chromosomal abnormalities, feeding problems causing inadequate nutrition and malabsorption that occurs because of edematous gastrointestinal system in those with chronic heart failure. Chronic cyanosis and heart failure dysfunction body metabolism and the susceptibility to infection again will result higher body metabolism. Those children with $\mathrm{CHD}$ and undernutrition have worse prognosis implicated by poor somatic growth, repetitive admissions, unfavorable outcome after intervention and finally they will succumb to death (6).

Anthropometry means the study of human body measurements in comparative bases. It utilizes primarily indices of growth which includes weight, stature (length/height) and head circumference especially for younger children. Triceps skinfold thickness, subscapular skinfold thickness, and mid-upper arm circumference are secondary measures to estimate the body composition (4). Percentile curves are used to compare the measured values to normal ranges of population data 
medRxiv preprint doi: https://doi.org/10.1101/2021.04.12.21255315; this version posted April 19, 2021. The copyright holder for this preprint

(which was not certified by peer review) is the author/funder, who has granted medRxiv a license to display the preprint in perpetuity.

All rights reserved. No reuse allowed without permission.

[Type text]

\subsection{STATEMENT OF THE PROBLEM}

Congenital heart disease is a major cause of morbidity and mortality in pediatric age group. Earlier to the era of echocardiography clinicians were not able to detect milder forms which has under estimated the incidence of congenital heart disease to the level of 5 to 8 per 1000 live births. But later echocardiography avoided this drawback, and the estimate reaches to eight to twelve per 1000 live births. Relatively larger number children are expected to be born with congenital heart disease in developing countries owing to higher fertility rate in these countries ( $4 \& 7)$.

Worldwide, of all the congenital malformation, CHD is the most common one and is responsible for $20 \%$ of all prenatal deaths (3).

Significant percentage of undernutrition and short stature seen in children with congenital heart disease. The presence of malnutrition will prone them for infection and the prognosis is grave even if correction is done later in life. The chance of developing malnutrition increases in those having CHD with cyanosis, multiple heart defects, heart failure, delayed intervention, anemia and pulmonary hypertension. Because of multiple reasons children with CHD in developing countries wont have an opportunity for corrective intervention which indirectly makes them susceptible to develop malnutrition (7-10).

For the above mentioned reasons, risk factors and associated comorbidities, malnutrition is a common finding we see in our patients with CHD, complicating the course and outcome of the disease.

Despite the significant morbidity and mortality associated with undernutrition in CHD, very little emphasis has been given in the management and prevention of this complication in our clinical practice. 
[Type text]

\subsection{SIGNIFICANCE OF THE STUDY}

Children with CHD and from developing countries are at increased of malnutrition because of additional risk factors other than the CHD itself. These are food insecurity, poverty, overcrowding, poor health seeking behavior and high prevalence of infections (11\&12)

Assessing the nutritional status of a child with congenital heart disease is crucial but not given due emphasis in the practice (4).

The purpose of this study is thus to determine the burden and determinants of undernutrition in CHD patients admitted and on follow up at St. Paul millennium medical college and at children cardiac center- Ethiopia. The conclusion obtained from such study will help to give an advice for health professionals to emphasis on nutritional assessment of patients with CHD and respective measures either to prevent it or early intervention to avoid additional complications. The results of this study can be used as an initiative to device guidelines and Nutrition goals for infants \& children with congenital heart disease to provide adequate calories and protein, considering potentially increased needs, and promote optimal weight gain and growth velocity. 
medRxiv preprint doi: https://doi.org/10.1101/2021.04.12.21255315; this version posted April 19, 2021. The copyright holder for this preprint (which was not certified by peer review) is the author/funder, who has granted medRxiv a license to display the preprint in perpetuity.

All rights reserved. No reuse allowed without permission.

[Type text]

\section{LITERATURE REVIEW}

In the study which has involved 194 children with congenital heart disease whose age is less than 15 years at Mulago National Referral Hospital and Uganda Heart Institute, Kampala from August 2013 to March 2014 found out the prevalence of wasting, underweight, thinness and stunting were $31.5 \%, 42.5 \%, 27.3 \%$ and $45.4 \%$ respectively. In those with heart failure and moderate to severe anemia the prevalence was higher.

Comparing this result with similar cross-sectional descriptive study done in Nigeria from November 2014 to April 2017, there was higher numbers of wasting, underweight and stunting in the Nigeria study accounting for $60.8 \%, 72.9 \%$ and $57.8 \%$ respectively. The explanation given for this higher figure is it might indirectly reflect the socio-economic status of the given population. Other confounding factors like severity of the disease, delayed presentation and frequent infections were not included in the study (7\&9).

Other study done in Scotland, concluded that Children with congenital heart disease are frequently undernourished, irrespective of the nature of cardiac defect and the presence or absence of cyanosis, but compared to the anthropometric results of the developing countries the values were low. $52 \%$ had weight less than the third centile, $37 \%$ were below the third centile for height(2).

A descriptive study was carried out in Baghdad university, Iraq, on 65 children aged $0-<5$ years with congenital heart disease have $32.3 \%$ suffered from underweight by weight for age, $64.6 \%$ of study sample suffered from wasting with weight for height, and $78.5 \%$ suffered from stunting with height for age(4).

A case control study from Zagazig University Children's Hospital, Egypt, from June 2012 to June 2013 which has included 100 pediatric patients with age range from 2 months to 6 years has shown $12(14.3 \%)$ were Underweight , 20 (23.8\%) were wasted and 52 (61.9\%) were Stunted (13). 
[Type text]

\section{OBJECTIVES}

\subsection{General objective}

To determine the burden of malnutrition and associated factors in pediatric patients with congenital heart disease who are on cardiac follow up at cardiac center-Addis Ababa Ethiopia.

\subsection{Specific objective}

\section{METHODOLOGY}

\subsection{Study area}

This study was conducted at pediatrics cardiac clinic of cardiac center - Ethiopia. Cardiac center - Ethiopia located within Black Lion hospital compound, Addis Ababa - Ethiopia was established in 2009 under a non-governmental and charitable organization called The Children's Heart Fund of Ethiopia (CHFE) with the objective of establishing a sustainable cardiac center which delivers universal standard cardiac care for children. Since the principal day of its activity the center rendered its service for more than 5,000 patients free of charge.

\subsection{Study design and period}

A cross sectional, prospective, analytic study was conducted over a period of 6months (February 2020 to July 2020). 
medRxiv preprint doi: https://doi.org/10.1101/2021.04.12.21255315; this version posted April 19, 2021. The copyright holder for this preprint (which was not certified by peer review) is the author/funder, who has granted medRxiv a license to display the preprint in perpetuity.

[Type text]

\subsection{Source and Study population}

\section{Source population}

All pediatric patients with congenital heart disease age $0-18$ yrs seen at outpatient clinic of children's cardiac center.

\section{Study population}

All pediatric patients with congenital heart disease age 0 - 18yrs seen at outpatient clinic of children's cardiac center during the study period.

\subsection{Inclusion criteria}

All pediatric patients age $0-18$ yrs with congenital heart disease seen at outpatient clinic of children's cardiac clinic whom didn't undergone intervention.

\subsection{Exclusion criteria}

All patients with risk factors other than CHD that contribute to malnutrition like genetic disorders, chronic illness, prematurity and low birth weight were excluded.

\subsection{Sample size determination and sampling technique}

The sample size was determined using the single population proportion formula, taking prevalence $(\mathrm{P})$ of $84 \%$ from a research done in Egypt, $\mathrm{Z}=1.96$, and assuming a $10 \%$ nonresponse rate, giving the total sample size to be $\mathbf{2 2 8}$.

Study subjects fulfilling the inclusion criteria were included consecutively until sample size is reached.

\subsection{Data collection}

Data collection was conducted by a trained general practitioner using a structured data inquiry sheet developed by the primary investigator. The data inquiry sheet included demographic characteristics including age, gender, age of diagnosis, social status of the parents and Other data including cardiac diagnosis at echocardiography, presence of pulmonary hypertension, weight, height, length, and body mass index. Relevant laboratory result like hemoglobin was included. 
medRxiv preprint doi: https://doi.org/10.1101/2021.04.12.21255315; this version posted April 19, 2021. The copyright holder for this preprint (which was not certified by peer review) is the author/funder, who has granted medRxiv a license to display the preprint in perpetuity.

[Type text]

\subsection{Method of data collection, tool and personnel}

A convenient sampling technique was used to include subjects that fulfilled the inclusion criteria that visited the cardiac clinic at the time of data collection until the sample size was achieved.

Weight was measured by a single person with the same weight scale.

Height was measured using a tape meter when the patient is lying in supine position flat on a rigid surface for those below two years and for those above two years who can't stand.

WHO Z- score classification for malnutrition is used to assess and categorize the nutritional status of these children included in our study. Acute malnutrition assessed by weight/length score, chronic malnutrition assessed by length/age score, while poor nutrition assessed by weight/age score.

\subsection{Data processing and analysis}

Interpretation of anthropometric values was based on the WHO Z-scores, interpreted as moderate and severe wasting if weight for height is $<-2 \mathrm{SD}$ to $>-3 \mathrm{SD}$ and $<-3 \mathrm{SD}$ respectively.

Moderately and severely underweight if weight for age is <- 2SD to > - 3SD and < -3SD respectively.

Moderately and severely stunted if length/height for age was <- 2SD to > - 3SD and < $3 \mathrm{SD}$ respectively.

Data analysis was done using SPSS version 25 statistical package. Individual questionnaires was checked before data entry into the software. Further data cleaning was performed to check for outliers, missed values and any inconsistencies before the data were analyzed using the software.

Pearson's chi square and fisher-exact test was used to find the association between categorical variables and For variables with p-value less than 0.20 in univariable logistic regression, multivariable logistic regression analyses were conducted to control the cofounders and to assess the association between independent variables and nutritional status. A p-value of $\leq 0.05$ was considered significant.

\subsection{Result dissemination plan}


medRxiv preprint doi: https://doi.org/10.1101/2021.04.12.21255315; this version posted April 19, 2021. The copyright holder for this preprint (which was not certified by peer review) is the author/funder, who has granted medRxiv a license to display the preprint in perpetuity. All rights reserved. No reuse allowed without permission.

[Type text]

The results of this research are presented to SPHMMC's department of pediatrics and child health. The findings will be published in a relevant scientific journal so that they can be of use for other academic researchers and clinical practitioners.

\subsection{Ethical consideration}

The study was approved by IRB of SPHMMC according to Ethiopian national research guideline. The privacy and confidentiality of all participants was secured, and informed written consent was taken from all study subjects. 
medRxiv preprint doi: https://doi.org/10.1101/2021.04.12.21255315; this version posted April 19, 2021. The copyright holder for this preprint (which was not certified by peer review) is the author/funder, who has granted medRxiv a license to display the preprint in perpetuity.

All rights reserved. No reuse allowed without permission.

[Type text]

\section{RESULTS}

A total of 228 children with congenital heart disease were included in the research. The mean age was 4.7years (SD 3.8yrs) and range of 3months to $17 \mathrm{yrs}$.see table 1.

Table 1 Socio-demographic characteristics of the study participants at the cardiac center Ethiopia

\begin{tabular}{|c|c|c|c|}
\hline \multicolumn{2}{|l|}{ Variables } & Frequency & Percent \\
\hline \multirow{4}{*}{ Age group } & $<1$ years & 35 & 15.3 \\
\hline & 1-3 years & 73 & 31.9 \\
\hline & $3-5$ years & 44 & 19.2 \\
\hline & $>5$ years & 76 & 33.2 \\
\hline \multirow[t]{2}{*}{ Gender } & Male & 102 & 44.7 \\
\hline & Female & 126 & 55.3 \\
\hline \multirow[t]{2}{*}{ Residence } & Urban & 105 & 46.1 \\
\hline & Rural & 123 & 53.9 \\
\hline \multirow[t]{4}{*}{ Religion } & Orthodox & 130 & 57.0 \\
\hline & Muslim & 74 & 32.5 \\
\hline & Protestant & 23 & 10.1 \\
\hline & Catholic & 1 & 0.4 \\
\hline \multirow[t]{4}{*}{ School level } & PKG & 174 & 76.3 \\
\hline & Grade 1-4 & 45 & 19.7 \\
\hline & Grade 5-8 & 7 & 3.1 \\
\hline & Grade 9-12 & 2 & 0.9 \\
\hline \multicolumn{4}{|l|}{ Parental } \\
\hline \multirow[t]{3}{*}{ Marital status } & Single & 1 & 0.4 \\
\hline & Married & 225 & 98.7 \\
\hline & Widowed & 2 & 0.9 \\
\hline \multicolumn{4}{|l|}{ Parental } \\
\hline \multirow[t]{5}{*}{ Education level } & Can't Read or Write & 16 & 7.0 \\
\hline & Read and Write & 18 & 7.9 \\
\hline & Below high school & 84 & 36.8 \\
\hline & Complete high school & 48 & 21.1 \\
\hline & College graduate & 62 & 27.2 \\
\hline \multirow[t]{5}{*}{ Occupation } & Farmer & 41 & 18.0 \\
\hline & Government employee & 54 & 23.7 \\
\hline & Daily laborer & 31 & 13.6 \\
\hline & Merchant & 19 & 8.3 \\
\hline & Private employee & 83 & 36.4 \\
\hline \multirow[t]{4}{*}{ Monthly income } & $<1000$ birr & 38 & 16.7 \\
\hline & 1001-3000 birr & 109 & 47.8 \\
\hline & 3001-5000 birr & 42 & 18.4 \\
\hline & $>5000$ birr & 39 & 17.1 \\
\hline
\end{tabular}

Majority of the study subjects have Acyanotic congenital heart disease (200/228) accounting for $87.7 \%$. The age at diagnosis for most of the patients is after 12month. See table 2.

Table 2: Clinical characteristics of CHD patients

\begin{tabular}{|ll|l|l|}
\hline Variables & & Frequency & Percent \\
\hline CHD type & $\begin{array}{l}\text { Acyanotic } \\
\text { Cyanotic }\end{array}$ & 200 & 87.7 \\
& & 28 & 12.3 \\
\hline
\end{tabular}


medRxiv preprint doi: https://doi.org/10.1101/2021.04.12.21255315; this version posted April 19, 2021. The copyright holder for this preprint (which was not certified by peer review) is the author/funder, who has granted medRxiv a license to display the preprint in perpetuity.

All rights reserved. No reuse allowed without permission.

[Type text]

\begin{tabular}{|l|l|l|l|}
\hline Age at diagnosis & \multicolumn{101}{c}{ month } & 15 & 6.6 \\
& $\mathbf{0 1}-\mathbf{1 2}$ months & 58 & 25.4 \\
\hline Pulmonary hypertension & Y12 months & 155 & 68.0 \\
\hline Anemia & No & 68 & 29.8 \\
& Yes & 159 & 69.7 \\
\hline Underweight & No & 34 & 14.9 \\
& No underweight & 194 & 85.1 \\
\hline Wasting & Moderate & 49 & 50.8 \\
& Severe & 63 & 21.5 \\
& No wasting & 134 & 27.6 \\
\hline Stunting & Moderate & 38 & 58.8 \\
& Severe & 56 & 16.7 \\
& No stunting & 130 & 24.6 \\
\hline & Moderate & 49 & 57 \\
\hline & Severe & 49 & 21.5 \\
\hline
\end{tabular}

Overall prevalence of underweight, wasting and stunting among CHD patients was $49.1 \%$, $41.3 \%$ and $43 \%$ respectively.

The commonest congenital heart disease was VSD occurring alone in $25 \%$ and co-exising with other congenital heart defects in $40.8 \%$ followed by PDA (15.4\%). The commonest cyanotic CHD is TOF occurring in $9.2 \%$ of all the CHDs. See table 3.

Table 3: Type and prevalence of cardiac defects among CHD patients

\begin{tabular}{|ll|l|l|}
\hline Types of CHD & & Frequency & Percent \\
\hline Acyanotic & VSD & 57 & 25.0 \\
& ASD & 22 & 9.6 \\
& PDA & 35 & 15.4 \\
& AVSD & 15 & 6.6 \\
& CoA & 1 & 0.4 \\
& PS & 12 & 5.3 \\
& AS & 10 & 4.4 \\
& VSD+ASD & 7 & 3.1 \\
& VSD+PDA & 15 & 6.6 \\
& VSD+PDA+CoA & 6 & 2.6 \\
& AVSD+PDA & 4 & 1.8 \\
& PS+VSD & 5 & 2.2 \\
& AS+PDA & 9 & 3.9 \\
\hline Cyanotic & TOF & 16 & 7.0 \\
& TOF+PA+PDA & 5 & 2.2 \\
& PA+PDA & 2 & 0.9 \\
& TGA+VSD & 3 & 1.3 \\
& TAPVR & 1 & 0.4 \\
\hline
\end{tabular}

From the 200 study subjects with acyanotic CHD, burden of underweight was $48 \%$, wasting was $41.5 \%$ and stunting was $42.5 \%$.

In the cyanotic CHD group, $53 \%$ of them were underweight, $35.7 \%$ were wasted and $42.8 \%$ of them were stunted. (see table 4). 
medRxiv preprint doi: https://doi.org/10.1101/2021.04.12.21255315; this version posted April 19, 2021. The copyright holder for this preprint (which was not certified by peer review) is the author/funder, who has granted medRxiv a license to display the preprint in perpetuity. All rights reserved. No reuse allowed without permission.

[Type text]

Table 4: Comparison of CHD patients with and without pulmonary hypertension based on their nutritional status

\begin{tabular}{|c|c|c|c|c|c|c|c|}
\hline Variables & & APAH & AWTPAH & $\begin{array}{l}X^{2}(P \\
\text { value })\end{array}$ & СРАН & CWTPAH & $\begin{array}{l}X^{2}(P \\
\text { value })\end{array}$ \\
\hline Underweight & $\begin{array}{l}\text { No } \\
\text { Yes }\end{array}$ & $\begin{array}{l}27 \\
39\end{array}$ & $\begin{array}{l}76 \\
57\end{array}$ & $5.7(0.057)$ & $\begin{array}{l}0 \\
2\end{array}$ & $\begin{array}{l}13 \\
13\end{array}$ & $1.9(0.17)$ \\
\hline Wasting & $\begin{array}{l}\text { No } \\
\text { Yes }\end{array}$ & $\begin{array}{l}33 \\
33\end{array}$ & $\begin{array}{l}83 \\
50\end{array}$ & $4.2(0.12)$ & $\begin{array}{l}1 \\
1\end{array}$ & $\begin{array}{l}17 \\
9\end{array}$ & $0.2(0.66)$ \\
\hline Stunting & $\begin{array}{l}\text { No } \\
\text { Yes }\end{array}$ & $\begin{array}{l}31 \\
35\end{array}$ & $\begin{array}{l}83 \\
50\end{array}$ & $5.6(0.06)$ & $\begin{array}{l}0 \\
2\end{array}$ & $\begin{array}{l}16 \\
10\end{array}$ & $2.9(0.09)$ \\
\hline
\end{tabular}

$\mathrm{X}^{2}=$ Chi square

Chi-square test was done to check if there is significant difference between CHD patients with PAH and without PAH based on their nutritional status using $\mathrm{P}<0.05$ as significant.

Among Acyanotic patients, PAH looks to have some degree of association with all underweight, wasting and stunting but no significant difference was observed between the two groups (acyanotic vs cyanotic).

Among cyanotic patients, PAH looks to have some degree of association with stunting but no significant difference was observed between patients with and without PAH based on their nutritional status.

Bivariate analysis was done to check if; Patient sex, age, residence, age at diagnosis, Acyanotic CHD, VSD, ASD, PDA, cyanotic CHD and TOF, have significant association with underweight at $\mathrm{P}<0.2$. Multivariable analysis was done to see if there is significant association of factors identified on bivariate analysis with outcome variable at $\mathrm{P}<0.05$.

Children's $>5$ years of age were 2.3 times more likely to be underweight than those between 1-3 years of age among CHD children's.

Children's with ASD were 70\% less likely to be underweight compared to other CHDs without ASD 70\% (95\% CI:0.1-0.9).(see table 5a)

Table 5a: Bivariate and multivariate analysis for Underweight

\begin{tabular}{|c|l|l|l|l|l|l|}
\hline Variables & $\begin{array}{l}\text { Underweight } \\
\text { (Yes) }\end{array}$ & $\begin{array}{l}\text { Normal } \\
\text { weight }\end{array}$ & $\begin{array}{l}\text { COR (95\% } \\
\text { CI) }\end{array}$ & P Value & AOR (95\% CI) & P Value \\
\hline $\begin{array}{r}\text { Residence } \\
\text { Rural }\end{array}$ & 59 & 46 & $\begin{array}{l}1.7(1.0-2.9) \\
1.0\end{array}$ & $0.05^{*}$ & $\begin{array}{l}1.6(0.9-2.8) \\
1.0\end{array}$ & 0.11 \\
Urban & 53 & 70 & & \\
\hline
\end{tabular}


medRxiv preprint doi: https://doi.org/10.1101/2021.04.12.21255315; this version posted April 19, 2021. The copyright holder for this preprint (which was not certified by peer review) is the author/funder, who has granted medRxiv a license to display the preprint in perpetuity. All rights reserved. No reuse allowed without permission.

[Type text]

\begin{tabular}{|c|l|l|l|l|l|l|}
\hline Age & & & & & & \\
$<1 \mathrm{yr}$ & 27 & 46 & $2.0(0.9-4.6)$ & $0.09^{*}$ & $2.3(0.9-5.3)$ & 0.053 \\
$1-3 \mathrm{yr}$ & 19 & 16 & 1.0 & & 1.0 & \\
$3-5 \mathrm{yr}$ & 21 & 23 & $1.6(0.7-3.3)$ & 0.3 & $1.6(0.7-3.5)$ & 0.2 \\
$\quad>5 \mathrm{yr}$ & 45 & 31 & $2.5(1.3-4.8)$ & $0.01^{*}$ & $2.3(1.1-4.5)$ & $0.02^{*}$ \\
\hline ASD & 6 & 16 & $0.4(0.1-0.9)$ & $0.04^{*}$ & $0.3(0.1-0.9)$ & $0.03^{*}$ \\
Yes & 106 & 100 & 1.0 & & 1.0 & \\
No & 100 & &
\end{tabular}

Bivariate analysis was done to check if; Patient sex, age, residence, age at diagnosis, Acyanotic CHD, VSD, ASD, PDA, PAH, cyanotic CHD and TOF, have significant association with wasting at $\mathrm{P}<0.2$. Multivariable analysis was done to see if there is significant association of factors identified on bivariate analysis with outcome variable at $\mathrm{P}<0.05$

As described in table 5b, Children's with PAH are more likely to have wasting compared to those without PAH with an odds of 1.9 (95\% CI: 1.0-3.4) among children's with CHD

Table 5b: Bivariate and multivariate analysis for wasting

\begin{tabular}{|c|c|c|c|c|c|c|}
\hline Variables & $\begin{array}{r}\text { Wasting } \\
\text { (Yes) }\end{array}$ & $\begin{array}{r}\text { Wasting } \\
\text { (No) }\end{array}$ & $\begin{array}{l}\text { COR }(95 \% \\
\text { CI })\end{array}$ & P Value & AOR $(95 \% \mathrm{CI})$ & P Value \\
\hline $\begin{array}{c}\text { VSD } \\
\text { Yes } \\
\text { No }\end{array}$ & $\begin{array}{l}19 \\
75\end{array}$ & $\begin{array}{l}38 \\
96\end{array}$ & $\begin{array}{l}0.6(0.3-1.0) \\
1.0\end{array}$ & $0.16^{*}$ & $\begin{array}{l}0.6(0.3-1.2) \\
1.0\end{array}$ & 0.14 \\
\hline $\begin{array}{l}\text { PDA } \\
\text { Yes } \\
\text { No }\end{array}$ & $\begin{array}{l}19 \\
75\end{array}$ & $\begin{array}{l}16 \\
118\end{array}$ & $\begin{array}{l}1.9(0.9-3.9) \\
1.0\end{array}$ & $0.09 *$ & $\begin{array}{l}1.7(0.8-3.5) \\
1.0\end{array}$ & 0.19 \\
\hline $\begin{array}{c}\text { PAH } \\
\quad \text { Yes } \\
\quad \text { No }\end{array}$ & $\begin{array}{l}34 \\
60\end{array}$ & $\begin{array}{l}34 \\
100\end{array}$ & $\begin{array}{l}1.7(0.9-2.9) \\
1.0\end{array}$ & $0.08 *$ & $\begin{array}{l}1.9(1.0-3.4) \\
1.0\end{array}$ & $0.04 *$ \\
\hline
\end{tabular}

Bivariate analysis was done to check if; Patient sex, age, residence, age at diagnosis, Acyanotic CHD, VSD, ASD, PDA, cyanotic CHD and TOF, have significant association with stunting at $\mathrm{P}<0.2$. Multivariable analysis was done to see if there is significant association of factors identified on bivariate analysis with outcome variable at $\mathrm{P}<0.05$ Children's with ASD have decreased chance of being stunted by 70\% (95\% CI: 0.1-0.9) compared to those CHD without ASD.

Children's with PAH are more likely to be stunted compared to those without PAH with an odds of 1.9 (95\% CI: 1.0-3.4) among children's with CHD. (see table 5c).

Table 5c: Bivariate and multivariate analysis for stunting

\begin{tabular}{|l|l|l|l|l|l|l|}
\hline Variables & Stunting & Stunting & COR $(95 \%$ & P Value & AOR (95\% CI) & P Value \\
\hline
\end{tabular}


medRxiv preprint doi: https://doi.org/10.1101/2021.04.12.21255315; this version posted April 19, 2021. The copyright holder for this preprint (which was not certified by peer review) is the author/funder, who has granted medRxiv a license to display the preprint in perpetuity.

[Type text]

\begin{tabular}{|c|c|c|c|c|c|c|}
\hline & (Yes) & (No) & \begin{tabular}{|l|} 
CI) \\
\end{tabular} & & & \\
\hline $\begin{array}{r}\text { Residence } \\
\text { Rural } \\
\text { Urban }\end{array}$ & $\begin{array}{l}53 \\
45\end{array}$ & $\begin{array}{l}52 \\
78\end{array}$ & $\begin{array}{l}1.8(1.0-3.0) \\
1.0\end{array}$ & $0.04 *$ & $\begin{array}{l}1.7(0.9-2.9) \\
1.0\end{array}$ & 0.06 \\
\hline $\begin{array}{cc}\text { ASD } & \\
& \text { Yes } \\
& \text { No }\end{array}$ & $\begin{array}{l}5 \\
93\end{array}$ & $\begin{array}{l}17 \\
113\end{array}$ & $\begin{array}{l}0.4(0.1-1.0) \\
1.0\end{array}$ & $0.05^{*}$ & $\begin{array}{l}0.3(0.1-0.9) \\
1.0\end{array}$ & $0.04 *$ \\
\hline $\begin{array}{r}\text { PAH } \\
\quad \text { Yes } \\
\quad \text { No }\end{array}$ & $\begin{array}{l}37 \\
61\end{array}$ & $\begin{array}{l}31 \\
99\end{array}$ & $1.9(1.1-3.4)$ & $0.02^{*}$ & $1.9(1.0-3.4)$ & $0.03 *$ \\
\hline
\end{tabular}

\section{DISCUSSION}

Children with CHD usually do not exhibit failure to thrive at the time of birth and during neonatal period unless the CHD is hemodynamically significant during that period. Otherwise, it usually become apparent after few weeks of like when the pulmonary pressure declined to its nadir. The severity and degree of malnutrition rely on mainly additional factors which characterizes the CHD. These are presence of cyanosis, development of heart failure and pulmonary hypertension (15).

Indian study of anthropometric data in children revealed documented dietary intake and socioeconomic level didn't affect the chance of being malnourished. . Similarly, in this study educational level, occupational and socioeconomic status were not found to have significant association with the occurrence of malnutrition in patients with CHD. In low- and middleincome countries, the prevalence of abnormal preoperative anthropometry is high attributed to late presentation, delays in corrective intervention, and frequent hospitalizations related to respiratory infections (6).

In this study of 228 participants the overall burden of underweight was $49.1 \%$. Among the acyanotic group $48 \%$ were underweight which is lower than the cyanotic group where prevalence reaches 53\%. In a similar study done in Uganda, involving 194 children with CHD, underweight assessed for those 0-10years, accounted for 42.5\%. (7). Oday Faris Washeel and his colleagues found out underweight accounted for $32 \%$ of the 65 studied subjects, 0-5years with CHD who visited the heart center in Nursing College, Al-Muthanna University, Samawah, Iraq. (5). On the other hand, an Indian study to identify determinants of malnutrition in children with congenital heart disease (CHD) which involved 476 preoperative patients, found a higher underweight percentage, 59\%. (6). 
medRxiv preprint doi: https://doi.org/10.1101/2021.04.12.21255315; this version posted April 19, 2021. The copyright holder for this preprint (which was not certified by peer review) is the author/funder, who has granted medRxiv a license to display the preprint in perpetuity. All rights reserved. No reuse allowed without permission.

[Type text]

The overall prevalence of wasting in this study was $41.3 \%$. Children with acyanotic CHD were observed to have a higher percentage of wasting as compared to those with cyanotic CHD, accounting $41 \%$ and $35 \%$, respectively. This percentage is higher in the Indian and Ugandan study where wasting was detected in $56 \%$ and $58 \%$ of the children with CHD respectively (6\&7). An even higher percentage was reported from the study in Al-Muthanna University, Samawah, Iraq, 64\%, which was attributed to premature delivery and low birth weight (5). Infants delivered premature and with low birth weight were excluded from this study.

Ninety seven out of the 228 study subjects were found to be stunted which equals $43 \%$ and no significant difference was seen between the cyanotic and acyanotic CHD. Comparable result was seen in the Ugandan study with stunting of $45 \%$. (7).

In this study pulmonary hypertension is associated with increased risk of being wasted (OR 1.9 (95\% CI: 1.0-3.4)) and stunted (OR 1.9 (95\% CI: (1.0-3.4)). Acyanotic patients with PAH looks to have some degree of association with all underweight, wasting and stunting but no significant difference on the risk of malnutrition between acyanotic and cyanotic CHD.

In contrast to ours, findings from the study done by Ijeoma Arodiwe and his colleagues stated that sever malnutrition and stunting were seen more in those with cyanotic CHD and developed pulmonary hypertension in comparison to acyanotic heart disease who were only wasted (4). In another study by Varan B, Tokel K and Yilmaz G. to compare the development of malnutrition in cyanotic and acyanotic ones in the presence and absence of pulmonary hypertension, they found out those with cyanotic CHD are likely to develop stunting than wasting, and out of which who developed pulmonary hypertension are severely affected (16).

Of the total patients 34 (14.9\%) of them had anemia with variable degree of severity from mild to severe and it was not found to have association with increased risk of malnutrition in this study; but in Ugandan study they found out association and those children are with moderate or severe anemia (7).

The other finding in this study is the decreased risk of being underweight and stunted (70\% (95\% CI: 0.1-0.9)) in children with ASD than those CHD without ASD. 
[Type text]

In the Indian study, they concluded, among many other risk factors identified, older age at surgical correction of the CHD was associated with increased risk of malnutrition and poor recovery after surgery (6). Similar conclusion was made in the Nigerian study where they found Children in the older age group and those presenting late are more prone to malnutrition and poor growth (4). The finding in this study was also similar to the above findings. It was found that children above 5years of age are 2.3 times more likely to be underweight.

\section{Limitations of the study}

This study failed to assess an important contributing factor to malnutrition in CHD, that is CHF. This was not possible because study subjects were on outpatient follow up only.

The limited no of cyanotic patients included in the study also made comparing the two groups difficult (cyanotic vs acyanotic).

\section{Conclusion}

Malnutrition is a major problem in children with congenital heart disease. This indicates that proper and routine nutritional assessment should be part of the care while dealing with such patients and appropriate measures need to be undertaken this problem. Subsequent studies with larger sample size may strengthen the findings in this research and also the impact of malnutrition in such patients can further be studied in detail.

\section{References}


medRxiv preprint doi: https://doi.org/10.1101/2021.04.12.21255315; this version posted April 19, 2021. The copyright holder for this preprint (which was not certified by peer review) is the author/funder, who has granted medRxiv a license to display the preprint in perpetuity. All rights reserved. No reuse allowed without permission.

[Type text]

1. Tamirat M. Congenital heart defects and associated factors in children with congenital anomalies. Ethiopian medical journal 2018;(October) 56(4): 335-341

2. Pollock CS. Nutritional status of children with congenital heart disease. 1995;277-83.

3. Argent AC, Balachandran R, Vaidyanathan B, Khan A, Kumar RK. Management of undernutrition and failure to thrive in children with congenital heart disease in lowand middle-income countries. Cardiol Young. 2017 Dec;27(S6):S22-S30. doi: 10.1017/S104795111700258X. PMID: 29198259.

4. Ijeoma Arodiwe, Josephat Chinawa, Fortune Ujunwa, et.al Nutritional status of congenital heart disease ( CHD ) patients $\square$ : Burden and determinant of malnutrition at university of Nigeria teaching hospital Ituku - Ozalla , Enugu. Pak J Med Sci 2015 Sep-Oct; 31(5): 1140-1145.

5. Oday Faris Washeel and Eqbal Ghanim Ali Ma'ala: Nutritional status of children with congenital heart disease; IJPSR, 2019; Vol. 10(2): 933-938.

6. Vaidyanathan B, Nair SB, Sundaram KR, Babu UK, Shivaprakasha K, Rao SG, Kumar RK. Malnutrition in children with congenital heart disease (CHD) determinants and short term impact of corrective intervention. Indian Pediatr. 2008 Jul;45(7):541-6. PMID: 18695271.

7. Batte, A., Lwabi, P., Lubega, S. et al. Wasting, underweight and stunting among children with congenital heart disease presenting at Mulago hospital, Uganda. BMC Pediatr 17, 10 (2017).

8. Hoffman JIe. The global burden of congenital heart disease. Cardiovasc J Afr. 2013 May;24(4):141-5. doi: 10.5830/CVJA-2013-028. PMID: 24217047; PMCID: PMC3721933.

9. Tankeu AT, Bigna JJ, Nansseu JR, et al. Prevalence and patterns of congenital heart diseases in Africa: a systematic review and meta-analysis protocol. BMJ Open. 2017;7(2):e015633. Published 2017 Feb 14. doi:10.1136/bmjopen-2016-015633

10. Oyarzún I, Claveria C, Larios G, Le Roy C. Nutritional recovery after cardiac surgery in children with congenital heart disease. Rev Chil Pediatr. 2018 Feb;89(1):24-31. English, Spanish. doi: 10.4067/S0370-41062018000100024. PMID: 29664500.

11. Irving, Sharon Y., "Patterns of Weight Change in infants With Congenital Heart Disease Following Neonatal Surgery: Potential Predictors of Growth Failure" (2011). Publicly Accessible Penn Dissertations. 443. 
medRxiv preprint doi: https://doi.org/10.1101/2021.04.12.21255315; this version posted April 19, 2021. The copyright holder for this preprint

(which was not certified by peer review) is the author/funder, who has granted medRxiv a license to display the preprint in perpetuity.

All rights reserved. No reuse allowed without permission.

[Type text]

12. Ingeborg Krieger and You C. Chen, Calorie requirements for weight gain in infants with growth failure due to maternal deprivation, undernutrition, and congenital heart disease: a correlation analysis: American academy of Pediatrics 1969;44;647

13. Hassan BA, Albanna EA, Morsy SM, Siam AG, Al Shafie MM, Elsaadany HF, Sherbiny HS, Shehab M, Grollmuss O. Nutritional Status in Children with UnOperated Congenital Heart Disease: An Egyptian Center Experience. Front Pediatr. 2015 Jun 15;3:53. doi: 10.3389/fped.2015.00053. PMID: 26125014; PMCID: PMC4467172.

14. Vieira, Tais Cleto Lopes, Trigo, Marlene, Alonso, Rosiris Roco, Ribeiro, Regina Helena Cunha, Cardoso, Maria Regina Alves, Cardoso, Antonio Carlos Alves, \& Cardoso, Maria Aparecida Alves. (2007). Assessment of food intake in infants between 0 and 24 months with congenital heart disease. Arquivos Brasileiros de Cardiologia, 89(4), 219-224.

15. Togănel, R. (2013). Nutritional Approach of Pediatric Patients Diagnosed with Congenital Heart Disease. Acta Medica Marisiensis, 59(2), 121-125.

16. Birgül Varan, Kürsad Tokel, Gonca Yilmaz. Malnutrition and growth failure in cyanotic and acyanotic congenital heart disease with and without pulmonary hypertension. Arch Dis Child. 1999;81:49-52. doi:10.1136/adc.81.1.49

17. World Health Organization. Haemoglobin concentrations for the diagnosis of anaemia and assessment of severity. Geneva: Vitamin and Mineral Nutrition Information System; 2011.

\section{All Authors declared that there is no conflict of interest for this manuscript to be published.}

